\title{
ASSESSMENT OF AGRICULTURAL CREDIT SOURCES AND ACCESSIBILITY IN NIGERIA
}

\author{
Ikenna Charles UKWUABA ${ }^{1}$, Zechariahs Benapugha OWUTUAMOR *2 (D), Cynthia C. OGBU ${ }^{1}$
}

\author{
Address: \\ ${ }^{1}$ University of Nigeria Nsukka, Faculty of Agriculture, Department of Agricultural Economics, Main Campus Nsukka, \\ 410001 Nsukka, Enugu State \\ ${ }^{2}$ Federal Polytechnic Ekowe, School of Agricultural Technology, Department of Agricultural Extension and \\ Management, Ekowe, 560103 Ekowe, Bayelsa State \\ * Corresponding author: ilsignorzax@gmail.com
}

\begin{abstract}
Rural and small holder famers in Nigeria and other developing countries have low capital base and poor access to finance. The inability of these farmers' access to adequate credit has increased the problem of low efficiency in production. Inadequate credit supply is a major problem with which other production factors may exert negative influence on farmers' output and efficiency. In ascertaining the sources and accessibility of credit by crop farmers in Enugu-Ezike in Enugu State, Nigeria, the sources of credit to farmers, the socio-economic characteristics of crop farmers' that have access to credit, access to credit constraints and possible ways of improving farmers' access to credit were investigated. Primary data collected through the administration of questionnaire were analysed using descriptive statistics and probit regression. Results showed that most crop farmers obtained credit mainly for farming and have accessed credit through informal sources, with friends and relatives being the most popular source. Majority of the farmers, who obtained information about credit through phone calls agreed that there were no delays in loan approval. Although, probit regression revealed that the independent variables (gender, age, marital status, education, household size, farm size, membership of cooperatives and farming experience) were not significant in jointly affecting access to credit at all probability levels, however, membership of cooperatives had an individually negative significant relationship with access to credit at the $10 \%(\mathrm{p}<0.10)$ level. Recommendations that will improve access to credit include: increasing farmers' access to information; reducing loan acquisition rigidity; reducing interest rate; having bank account; establishment of community and agricultural banks in the rural areas with simple procedures for securing loans; and the mobilization of farmers into groups to maximize the benefit of collective investment or group savings.
\end{abstract}

Keywords: agricultural credit, access to credit, crop farmers, Enugu, probit regression JEL: Q12; Q14; C81

\section{INTRODUCTION}

Agricultural credit has shown to be a great contributing factor to agricultural productivity and efficiency (NNB, 2014), as such, Ijioma and Osondu (2015) posited that agricultural credit insufficiency has been considered a hindrance to the development of rural farmers in Nigeria and the world at large. Credit is defined as the ability to obtain title to, and receive goods for use in the present, although payment would be differed to a future date (Miler 1977). Dixon et al., (2001) described credit as the use of funds and services without immediate payment. However, agricultural credit is often discussed in monetary terms (Dixon et al., 2001; DBSA, 2005). Aku (1995) is of the opinion that agricultural credits are loans extended to farmers for production, storage, processing and marketing of farm products. Such credit can be short, medium or long term, depending on its duration. Credit institutions range from well-developed and large sized commercial banks to localized small cooperatives. It can also be formal or informal (Aku, 1995; CBN, 2004). Yet, Badiru (2010) noted that other authors categorized credit sources into three, by including the semiformal institutions such as non-governmental organisation microfinance institutions (NGO-MFIs) and cooperatives. The formal credit sources serve intermediary function between depositors and borrowers and impose lower rate interests on farmers, which are usually subsidized (Ijioma and Osondu, 2015). The formal institutions include commercial, microfinance and rural development banks that offer credit to large and medium scale farmers, considered credit worthy, due to their potential to provide collateral (Anyanwu, 2004). The informal credit sources are friends, families, Esusu, Ajo and merchant traders that tend to be more flexible and operate mainly in a particular market niche (Ghatak and Guinnane, 1999). According to Diagne and Zeller (2001), a farmer is said to have access if he is able to or entitled to borrow from a credit source (commercial banks, cooperative societies, money lenders, etc.). However, this study assumed access to credit, which is quite distinct from participation in the credit market, to be, when a farmer applies for credit and obtains at least $70 \%$ of the amount applied for.

The decline in agricultural productivity of the 
Nigerian economy is considered to be a function of lack of credit facilities that have prevented farmers from adopting new technologies, due mostly as a result of farmers' inability to provide collateral for loans collected from various sources (Asogwa, Abu and Ochoche, 2014). Some researchers like Carter (1989); Feder et al. (1990); Carter and Olinto (2003); Petrick (2004); Foltz (2004); Guirkinger and Boucher (2008); and Fletschner, Guirkinger and Boucher (2010) perceive agricultural credit efficiency as the foundation of agricultural productivity, farm investment and profit. Conversely, other researchers, for example, Kochar (1997) is of the opinion that agricultural productivity is not dependent on credit. Now, considering this contradiction in the opinion of researchers, it becomes vital to study credit intensively. Explaining the effect of agricultural credit on agricultural output, Hazarika and Guha-Khasnobis (2008) reported that agricultural credit can have a secondary spillover effect on non-farm households via input, labour and output linkages. When farmers face a credit constraint, additional credit supply can raise input use, investment and hence output. Where agriculture still remains a risky activity, better agricultural credit facilities can help farmers smoothen out consumption, and therefore, increase the willingness of risk averse farmers to take risks and make agricultural investments. Hence, a better agricultural credit may lead to a higher volume of food output if the increase in credit is used to increase fertilizer, private investment in machines and food crops.

On the course of formulation, implementation and evaluation of policy in agricultural sector; efficiency and availability of irrigation systems, utilization of improved seeds, fertilizer availability and the ease of access to agricultural credit are issues of interest. Amongst these, access to credit is the major focus of policy makers, this is because the ease or availability of credit will facilitate the application of the other factors. Thus, agricultural credit is a key resource in the development of agriculture in developing countries (Bashir, Mehmood and Hassan, 2010). Therefore, since credit is vital in the adoption of innovations that would lead to increase in farm productivity and income (Nwaru, Onyenweaku and Nwosu, 2006), its acquisition and effective utilization will bring about an increase in farm output and efficiency (Obwona, 2002).

In Nigeria, agriculture is the backbone of the economy because without food and basic raw materials industries will be in crisis. Rural farmers in Africa make up more than $75 \%$ of the labour force in agriculture and $80 \%$ food producers (Maigida 2001). These farmers are constrained by issues of poor access to innovation, poor infrastructure, inadequate access to markets, land and environmental degradation, poor extension and research services and finally the inability to consider and improve the financial requirements of these farmers (Lawal, 2011). The effect of finance in the development of any sector of the economy cannot be outsourced and agriculture is not an exception. Credit institutions in Nigeria, lack formal credit policy and paucity which can assist farmers to access credit and is one of the reasons for the decline in agricultural contribution to the economy (Olagunju and Ajiboye, 2010). Similarly, farmers are also faced with the problem of late loan release or disbursement, nonfulfilment of collateral requirements, diversification of funds by financial institutions for non-agricultural purposes (Nwaru, Essein and Onuoha, 2011). The informal or non-institutional sources of agricultural credit cannot be said to be adequate and efficient in terms of providing finance for crop production (Nwaru, 2004).

Furthermore, Magaja and Agai (N.D.); Awotide et al. (2015); Linh et al. (2019); Okoruwa et al. (2020) insinuated that rural and small holder famers in developing countries (such as Nigeria), have low capital base and poor access to finance. Thus, the inability of these farmers to have access to adequate credit has increased the problem of low efficiency in production. Inadequate credit supply is a major problem with which other production factors exert negative influence on farmers' output and efficiency. For farmers that were opportune to have access to credit, the problem of low efficiency in productions still comes up in situations where there is wide difference between the amount requested and the amount actually paid (Akinade, 2002). Considering the benefit of credit or finance in agriculture and other sectors, it is pertinent to study and analyse the sources of credit and the determinants of its accessibility by crop farmers.

Many research works have been carried out on access to agricultural credit (Diagne and Zeller, 2001; Nwaru, 2004; Muhammad at al., 2013); some tried to compare the effect of interest rate on access (Ali et al., 2017); some focused on access by specific farmers (Bashir, Mehmood and Hassan 2010); some worked on sources of credit (Guirkinger, 2008; Ijioma and Osondu, 2015; Mgbakor, Uzendu and Ndubuisi, 2014); some confined access to small scale farmers (Badiru, 2010; Asogwa, Abu and Ochoche, 2014), etc. These and many more works on this aspect stand to show that credit plays a vital role in agriculture. However, little or none has been carried out on crop farmers especially in Enugu Ezike Agricultural Zone of Enugu State, who are predominantly farmers. Thus, this work intends to fill the knowledge gap.

The broad objective of our study was to examine and analyze agricultural credit sources and its accessibility by crop farmers in Enugu-Ezike agricultural zone of Enugu State, Nigeria. The specific objectives include:

i. identifying the socio-economic characteristics of crop farmers;

ii. ascertaining the sources of credit to farmers;

iii. determining the socio-economic determinants of crop farmers' access to credit;

iv. identifying the constraints in the procurement of credit from formal sources; and

v. identifying the possible ways of improving farmers' access to credit.

\section{DATA AND METHODS}

\section{The Study Area}

This study was conducted in Enugu-Ezike agricultural zone of Enugu State, Nigeria. The zone is made up of three Local Government Areas (LGA), viz: Igbo-Eze North, Igbo-Eze South and Udenu LGAs with an aggregate population of 584,880 people (NPC 2006). The Enugu Ezike agricultural zone is situated at about 233 metres 
above sea level and has predominantly gravely-silt soil that is well drained all year round, mostly reddish in colour and has a high density bearing capacity for intense building construction. It lies within the northern fringes of the tropical rainforest zone and the southern end of the derived savannah vegetation belt, with two distinct alternating wet (rainy) and dry (harmattan) seasons, which lasts for about eight months and four months respectively. Its rainfall ranges from about $0.16 \mathrm{CM}^{3}$ in February and $35.7 \mathrm{CM}^{3}$ in July, with a mean temperature that ranges from about $15.86^{\circ} \mathrm{C}$ to $30.64^{\circ} \mathrm{C}$ (Ani, 2015; ESG, 2018). Farming is the major occupation and source of income in the zone, with crops such as maize, vegetables, yam, cassava, etc. being produced and livestock such as poultry, goat, sheep, pig, etc. being reared. They also engage in other occupations including civil service, trading, hunting, palm wine tapping and so on (William, 2008).

\section{Data collection}

Primary data were collected for the study by administering semi-structured questionnaires to selected farmers in a two stage random sampling technique. Stage one involved selecting ten (10) communities from each of the 3 LGAs giving a total of 30 communities. In the second stage, two (2) crop farmers were randomly selected from each of the 30 communities, giving a total of 60 respondents for the study.

\section{Data Analysis}

Descriptive statistics such as tables, frequencies and percentages were used to present and analyze data to achieve most of the objectives. A 4-points Likert scale type rating, having 'Strongly Agree', 'Agree', 'Disagree', and 'Strongly Disagree' was used to determine the problems or bottlenecks experienced by farmers which tend to hinder their access to credit. Probit regression analysis was done using a multiple linear model. Probit regression analysis was done using a multiple linear model because the dependent variable is a dichotomous variable. This was adopted in line with the study by Ajagbe (2012), who applied the probit regression model to determine the relationship between farmers' access to credit and their socioeconomic characteristics. The model is given below.

The implicit function of the regression model is given as Eq. 1.

$Y=f\left(X_{1}, X_{2}, X_{3}, X_{4}, X_{5}, X_{6}, X_{7}, X_{8}\right)$

While the explicit form is given in the linear equation (Eq.2):

$Y=\beta_{0}+\beta_{1} X_{1}+\beta_{2} X_{2}+\beta_{3} X_{3}+\beta_{4} X_{4}+\beta_{5} X_{5}+$

$\beta_{6} X_{6}+\beta_{7} X_{7}+\beta_{8} X_{8}+\varepsilon$

Where: $\mathrm{Y}=$ access to credit (when at least $70 \%$ of the amount requested is received), $X_{1}=$ age of the crop farmer (years), $X_{2}=$ gender of the farmer $($ male $=1$ or female $=0$ ), $\mathrm{X}_{3}=$ marital status (married $=1$, otherwise $=0$ ), $X_{4}=$ farm size (hectares), $X_{5}=$ educational level (No formal education $=0$, primary education $=1$, secondary education $=2$, tertiary education $=3$ ), $\mathrm{X}_{6}=$ farming experience (years), $X_{7}=$ ownership of land (own land=1, otherwise 0), $\mathrm{X}_{8}=$ membership of cooperatives (member $=1$, otherwise $0), \varepsilon=$ error term.

\section{RESULTS AND DISCUSSION}

\section{Socio-economic characteristics of the crop farmers}

The major attributes of individual crop farmers that were considered in the study are summarized in Table 1.

From Table 1, a higher percentage of the respondents fall within the ages of 21-40 years indicating that the farmers in the study area are young farmers. The statistic is important to the government and individual as it shows that even though, there are fears of high rural-urban migration, the population of young people in the rural areas are still high. The participation of young people is also a push factor towards innovation adoption as youths are likely to try out new methods and adopt new technologies than the older people. Majority of the respondents were male. This is most likely due to the fact that women in the study area are culturally not allowed to inherit land and farmers in Nigeria usually engage in labour-intensive agriculture, as corroborated by Ololade and Olagunju (2013). The high percentage of married respondents indicate that most of the farmers are saddled with a higher level of responsibility, as such, there is need to engage in economically productive activities that will provide them the resources needed to carter for their families, in supplying the basic needs of life, such as food, clothing, shelter and so on. Most respondents own farmlands ranging from one to five hectares, this may probably be the reason why most of the respondent's access to credit is through informal sources because they lack adequate collateral to offer for formal loan acquisition. Almost all the respondents have had at least one form of formal education or the other, making it easier for them to adopt innovations and circulate information, as such, learning will have a positive shift as education helps to increase awareness and acceptance of facts. The higher the farming experience, the more likely a farmer is to be trusted by formal credit sources, such as government agencies, commercial banks, etc. However, the result shows that many of the farmers have less than 10 years' experience in farming. This may also be one of the reasons why the crop farmers mostly lacked access to the formal sources of credit. Majority of the respondents owned the lands they farm on, this will bring about a positive impact in access to credit as the land owned can be used for collateral. However, the ability to use the lands as collateral will be dependent on the size of the land owned and the availability of documents indicating ownership. Many farmers do not belong to a cooperative, implying that most of the farmers will be constrained from accessing credit and will lack the benefits enjoyed by members of the cooperative society and as such, will have no option than to access credit from informal sources, rather than formal or semi-formal sources, where they can easily meet credit requirements.

\section{Farmers' access to credit}

Table 2 shows the information gathered from the crop farmers about their credits. 
Table 1: Descriptive statistics of the socioeconomic characteristics of the respondents

\begin{tabular}{|c|c|c|c|c|}
\hline $\mathrm{S} / \mathrm{N}$ & Socio-economic characteristics & & Frequency & Percentage \\
\hline \multirow[t]{4}{*}{$\overline{1 .}$} & Age & $21-40$ & 39 & 65 \\
\hline & & $41-60$ & 15 & 25 \\
\hline & & 61 and above & 6 & 10.0 \\
\hline & & Total & 60 & 100.0 \\
\hline \multirow[t]{3}{*}{2.} & Gender & Male & 43 & 71.7 \\
\hline & & Female & 17 & 28.3 \\
\hline & & Total & 60 & 100.0 \\
\hline \multirow[t]{3}{*}{3.} & Marital Status & Married & 51 & 85.0 \\
\hline & & Single/divorced/widowed, etc. & 9 & 15.0 \\
\hline & & Total & 60 & 100.0 \\
\hline \multirow[t]{4}{*}{4.} & Farm size & Below 1 ha & 10 & 16.7 \\
\hline & & $1-5$ ha & 45 & 75.0 \\
\hline & & Above 5 ha & 5 & 8.3 \\
\hline & & Total & 60 & 100.0 \\
\hline \multirow[t]{5}{*}{5.} & Education & No formal education at all & 2 & 3.3 \\
\hline & & Primary education & 12 & 20.0 \\
\hline & & Secondary education & 27 & 45.0 \\
\hline & & Tertiary education & 19 & 31.7 \\
\hline & & Total & 60 & 100.0 \\
\hline \multirow[t]{4}{*}{6.} & Farming experience (in years) & Less than 10 & 41 & 68.3 \\
\hline & & $11-30$ & 15 & 25.0 \\
\hline & & Over 30 & 4 & 6.7 \\
\hline & & Total & 60 & 100.0 \\
\hline \multirow[t]{3}{*}{7.} & Land ownership & Yes & 47 & 78.3 \\
\hline & & No & 13 & 21.7 \\
\hline & & Total & 60 & 100.0 \\
\hline \multirow[t]{3}{*}{8.} & Cooperative membership & Yes & 13 & 21.7 \\
\hline & & No & 47 & 78.3 \\
\hline & & Total & 60 & 100.0 \\
\hline
\end{tabular}

Source: Field survey

Table 2: Farmers' access to credit

\begin{tabular}{|c|c|c|c|c|}
\hline$\overline{\mathrm{S} / \mathrm{N}}$ & Item & & Frequency & Percentage \\
\hline \multirow[t]{3}{*}{$\overline{1 .}$} & Sources of credit & Formal & 24 & 40.0 \\
\hline & & Informal & 36 & 60.0 \\
\hline & & Total & 60 & 100.0 \\
\hline \multirow[t]{7}{*}{2.} & Ways of obtaining credit & Bank & 11 & 18.3 \\
\hline & & Friends and relatives & 34 & 56.7 \\
\hline & & Cooperatives & 1 & 1.7 \\
\hline & & Esusu & 7 & 11.7 \\
\hline & & Age group & 6 & 10.0 \\
\hline & & Church & 1 & 1.7 \\
\hline & & Total & 60 & 100.0 \\
\hline \multirow[t]{5}{*}{3.} & Reasons for obtaining credit & Farming & 46 & 76.7 \\
\hline & & Education & 3 & 5.0 \\
\hline & & Feeding & 1 & 1.7 \\
\hline & & Trading & 10 & 16.7 \\
\hline & & Total & 60 & 100.0 \\
\hline \multirow[t]{3}{*}{4.} & Delay in receiving credit & Yes & 28 & 46.7 \\
\hline & & No & 32 & 53.3 \\
\hline & & Total & 60 & 100.0 \\
\hline \multirow[t]{4}{*}{5.} & Information source & Radio and television & 10 & 16.7 \\
\hline & & Agric. extension agents & 9 & 15.0 \\
\hline & & Telephone calls & 41 & 68.3 \\
\hline & & Total & 60 & 100.0 \\
\hline
\end{tabular}

Source: Field survey 
The source of credit often chosen by farmers is dependent on the ease of accessibility and other factors. The result above shows that most of the farmers chose the informal sources over the formal sources. This may be probably due to the farmers' low farming experience, small farm size and non-cooperative membership. As seen in Table 2, a good percentage of the farmers source their credit from informal sources, such as friends and relatives, rather than from semi-formal sources like cooperatives and churches or formal sources like banks. Most probably due to the fact that the farmers can easily draw sympathy from these group of people and the conditions required to access such loans are usually not stringent. Thus, reflecting the important role played by friends and relatives in access to credit by crop farmers. Farmers access credit for several reasons, such as farming, trading, education, feeding, etc. Most of the farmers' source for credit for use in farming activities indicating that their interest is in increasing productivity or output, with a view to better their standard of living through agriculture. Although, a good proportion of the farmers agreed that there were delays in receiving the credits, a higher proportion, however revealed that they had no delays in receiving the credits. This is important because of the characteristics or nature of agricultural production in Nigeria, as farmers may decide to access credit for farming, especially at the critical points of the production process. Similarly, the greater the delay in credit approval, the lesser the farmers' access to credit. As the world is going digital, the use of radio and television and extension agents for information transmission is reducing. However, this does not mean that they are no longer useful. From the result obtained, the mostly used information source is the telephone. This means of information dissemination, is relatively cheap and saves time compared to others.

\section{Amount of credit sought and obtained}

The data collected in Table 3 reflects the actually amount of credit sought for, in Naira $(\mathrm{N})$ terms, by the crop farmers and the amounts that they actually obtained from their sources.

The average amount of credit a farmer sought for in the study area was N138,083.33K (about US\$386.25, at an exchange rate of $\mathrm{N} 357.5 / \mathrm{US} \$$ ), indicating that most of the farmers operate mostly on a subsistence level. This may be partly due to the fact that most times, the credit is often sought after production activities have commenced, perhaps at critical points, as the average amount sought is small and may be needed only for the acquisition of additional inputs in small quantities. An average amount of N110,583.33 (about US\$309.32) was received by a farmer who sought an average of N138,083.33 (about US\$386.25), thus, giving a difference of N27,500.00 (about US\$76.92) or $19.92 \%$ of the amount sought. Hence, it is advisable for the farmers to add a $19.92 \%$ to the amount of loan they are seeking from friends and relatives, if they really want to get the exact amount they should have sought for. For instance, a farmer who needs N200,000.00 (about US\$559.44) should be seeking for about N240,000.00 (about US\$671.33), since there is a high probability that (s)he will get $19.92 \%$ less than the amount requested as loan from relatives and friends.

\section{Socio-economic factors affecting access to credit}

The results of the probit regression done to determine which of the socio-economic characteristic of the crop farmers sampled had effect on farmers' access to credit is presented in Table 4.

Table 3: Amount sought for vs Amount obtained

\begin{tabular}{|c|c|c|c|c|c|c|}
\hline $\mathrm{S} / \mathrm{N}$ & Description & No. of Obs. $(\mathrm{N})$ & Min. & Max. & Mean & Standard Deviation \\
\hline 1. & Amount sought $(\mathrm{N})$ & 60 & $10,000.00$ & $800,000.00$ & $138,083.33$ & $206,521.00$ \\
\hline 2. & Amount obtained (N) & 60 & $10,000.00$ & $700,000.00$ & $110,583.33$ & $157,275.78$ \\
\hline
\end{tabular}

Table 4: Socio-economic factors affecting crop farmers' access to credit (Results of the probit regression)

\begin{tabular}{|c|c|c|c|c|c|}
\hline Variable & Coefficient & $\begin{array}{l}\text { Standard } \\
\text { Error }\end{array}$ & Z-score & $p>|z|$ & $95 \%$ Conf. Interval \\
\hline GENDER & -.0580001 & .5671005 & -0.10 & 0.919 & -1.1694971 .053496 \\
\hline AGE & -.0477376 & .0301484 & -1.58 & 0.113 & $\begin{array}{lll}-.1068273 & 0113522\end{array}$ \\
\hline MARITALST & .2541245 & .6642662 & 0.38 & 0.702 & $-1.047813 \quad 1.556062$ \\
\hline EDUCATION & -.1687247 & .1817173 & -0.93 & 0.353 & -.5248842 .1874347 \\
\hline HHDSIZE & .120358 & .1580503 & 0.76 & 0.446 & -.189415. 4301309 \\
\hline FARMSIZE & .0035204 & .1739192 & 0.02 & 0.984 & $\begin{array}{ll}-.337355 & .3443958\end{array}$ \\
\hline MEMCOOP & -1.075456 & .5754998 & -1.87 & 0.062 & $\begin{array}{ll}-2.203415 & .0525026\end{array}$ \\
\hline FARMEXP & .0240439 & .0346894 & 0.69 & 0.488 & -.043946 .0920338 \\
\hline Cons & 2.725033 & 1.188525 & 2.29 & 0.022 & .3955659 \\
\hline Number of Obs. & & 60 & & & \\
\hline $\mathrm{LR} \mathrm{Chi}^{2}(8)$ & & 11.68 & & & \\
\hline Prob $>\mathrm{Chi}^{2}$ & & 0.1660 & & & \\
\hline Log likelihood & & -26.755944 & & & \\
\hline Pseudo $\mathrm{R}^{2}$ & & 0.1792 & & & \\
\hline
\end{tabular}

Source: Authors' computation 
The socio-economic variables considered as independent variables for this study were gender (GENDER), age (AGE), marital status (MARITALST), education (EDUCATION), household size (HHDSIZE), farm size (FARMSIZE), co-operative membership (MEMCOOP) and farming experience (FARMEXP), while the dependent variable was farmers' access to credit (ACCTOCRE). From the results, we accept the null hypotheses and reject the alternative hypotheses, since the value of $\mathrm{prob}>\mathrm{Chi}^{2}(0.1660)$ is not significant at the $1 \%$ $(\mathrm{p}<0.01), 5 \%(\mathrm{p}<0.05)$ or $10 \%(\mathrm{p}<0.10)$ probability levels. As such, it can be deduced that all the variables jointly were not significant in affecting access to credit. Even though all the independent variables were jointly not significant in affecting farmers' access to credit at all probability levels, membership of a cooperative society with a coefficient of -1.075456 and a probability $(p>|z|)$ of 0.062 was; however, significant at the $10 \%(p<0.10)$ probability level. In essence, membership to cooperative societies has an inverse relationship with access to credit. This means that as membership to cooperative societies decreases by one unit, access to credit decreases by 1.075456 and vice versa, ceteris paribus. In other words, the more cooperative societies a crop farmer belongs to, the lower the access to credit and the lower the number of cooperatives a farmer belongs to, the higher the access to credit from friends and relatives. This is probably due to the fact that crop farmers who belong to one or more cooperative societies are most likely to access loans from their cooperative and other formal and semi-formal sources, rather than from friends and relatives. The result is similar to findings by Assogba et al. (2017), who suggested that belonging to farmers' cooperatives or associations was found to increase the likelihood of access to formal and semi-formal credit by $31 \%$. Conversely, the more a farmer has access to credit from friends and relatives, the less likely it will be, for the farmer to join a cooperative society, as there is probably no reason for a farmer to join a cooperative in order to be able to access credit from formal or semi-formal sources, since friends and relatives could provide the funds required without delays, with just a telephone call.

\section{Constraints to access to credit from formal sources}

Results obtained from the field study through the 4-points Likert scale type rating identified some constraints to access to credit from formal sources, as presented in Table 5.

Analysing the data presented in Table 5, lack of collateral can be seen to be a major contributing factor to lack of access to credit by crop farmers. Untimely disbursement of credit has also been seen as a factor constraining crop farmers' access to credit. Since most of the respondents either agreed or strongly agreed, interest rate can therefore be said to be a great contributing factor to crop farmer's access to credit. This is important because, whenever credit is mentioned, the enquiries to be made, normally starts from the interest rates involved. A good proportion of the crop farmers are of the opinion that lack of knowledge of the rules and regulation of banks on credit contribute to farmers' credit inaccessibility, thus, constituting a hinge to farmers' access to credit. Since most of the farmers either strongly agreed or agreed, lack of access to credit information also plays a major role in determining whether or not a farmer can access credit. Similarly, a greater proportion of the farmers opined that the transport cost involved in getting to the area where credit is available can also be a problem to farmers' access to credit. As such, the further away the credit source is from the farmers, the more likely their access is reduced. A high percentage of the farmers were in agreement that the difference between the amount requested and the amount released affects their accessibility to credit, hence, it is a factor of lack of access to credit. Most of the farmers believed that formal institutions issuing credit, are charged with procedures viewed by the farmers as complex. This perception of the farmers, prevents them from accessing credit. The crop farmers in the majority, held the view that farmers' access to formal credit can be reduced by delays in approving and obtaining credit.

\section{Possible ways of improving farmers' access to credit}

There are possible ways of improving farmers' access to credit, data collected from the field is presented in Table 6. The Likert type scale rating was used in collecting data on the ways by which farmers access to credit can be improved.

Table 5: Constraints to access to credit from formal sources

\begin{tabular}{|c|c|c|c|c|c|}
\hline $\mathrm{S} / \mathrm{N}$ & Constraint & $\begin{array}{l}\text { Strongly Agree } \\
(\%)\end{array}$ & $\begin{array}{l}\text { Agree } \\
(\%)\end{array}$ & $\begin{array}{l}\text { Disagree } \\
(\%)\end{array}$ & $\begin{array}{l}\text { Strongly Disagree } \\
(\%)\end{array}$ \\
\hline 1. & Lack of collateral & 20.00 & 73.33 & 6.67 & 0.00 \\
\hline 2. & Untimely disbursement of credit & 26.67 & 60.00 & 13.33 & 0.00 \\
\hline 3. & Interest rate & 48.33 & 45.00 & 5.00 & 1.67 \\
\hline 4. & Lack of knowledge of bank rules and regulations & 26.67 & 58.33 & 10.00 & 5.00 \\
\hline 5. & Lack of access to credit information & 50.00 & 36.67 & 8.33 & 5.00 \\
\hline 6. & Cost of transportation to the area of credit availability & 25.00 & 46.67 & 8.33 & 20.00 \\
\hline 7. & $\begin{array}{l}\text { Difference between the amount sought and the amount } \\
\text { obtained }\end{array}$ & 55.00 & 30.00 & 13.33 & 1.67 \\
\hline 8. & $\begin{array}{l}\text { Formal institutions issuing credit have procedures that } \\
\text { are complex }\end{array}$ & 33.33 & 45.00 & 15.00 & 6.67 \\
\hline 9. & Delays in approving and obtaining credit & 60.00 & 20.00 & 10.00 & 10.00 \\
\hline
\end{tabular}

Source: Field survey 
Table 6: Ways of improving farmers' access to credit

\begin{tabular}{|c|c|c|c|c|c|}
\hline$\overline{\mathrm{S} / \mathrm{N}}$ & Ways of improving access to credit & $\begin{array}{l}\text { Strongly Agree } \\
(\%)\end{array}$ & $\begin{array}{l}\text { Agree } \\
(\%)\end{array}$ & $\begin{array}{l}\text { Disagree } \\
(\%)\end{array}$ & Strongly Disagree (\%) \\
\hline 1. & Improve information access & 15.00 & 81.67 & 3.33 & 0.00 \\
\hline 2. & Availability of assets for collateral & 26.67 & 63.33 & 10.00 & 0.00 \\
\hline 3. & Reduced rigidity & 40.00 & 50.00 & 10.00 & 1.70 \\
\hline 4. & Interest rate subsidy & 35.00 & 50.00 & 11.67 & 3.33 \\
\hline
\end{tabular}

Source: Field survey

The result in Table 6 shows that to improve access to credit, information access should be improved, since almost all the farmers agreed that improved information access improves farmer's access to credit. Similarly, majority of the farmers see the availability of assets to be used as collateral as an important factor to farmer's access to credit. Apart from availability of assets for collateral, most crop farmers believed that reduced rigidity can serve as a means of improving access to credit to farmers. Also, a greater proportion of the farmers were of the opinion that if interest rates were subsidized, it will improve their access to credit.

\section{CONCLUSION}

Crop farmers in Enugu-Ezike agricultural zone, through telephone calls obtain credit from informal sources, mostly from friends and relatives for investment in farming activities without delays. With an average amount of N138,083.33 (about US\$386.25) sought, the farmers get about N110,583.33 (about US\$309.32) or 80\% of the credit they seek. None of the socio-economic variables were significant at the 1 and 5\% probability levels, with only membership of cooperatives being significant at the $10 \%$ probability level. Farmers were constrained to access credit due to factors such as lack of collateral, untimely disbursement of funds, unfavourable interest rates, lack of knowledge of bank rules and regulations, lack of access to credit source, difference between amount sought and obtained, cumbersome procedures of formal credit sources and delays in obtaining credit. However, farmers' access to credit can be improved through improved access to information, availability of collateral, reduced rigidity of credit administration and availability of subsidized credit.

It is obvious that small scale farmers form the bulk of agricultural producers in Nigeria, thus, it is necessary to encourage agricultural development through the provision of credit, enhancing accessibility to credit and educating farmers on how to put the credit obtained to effective use in order to increase their productivity and output, thereby, ensuring food security

This study recommends as follows:

i. The amount allocated to the agricultural sector in the national budget is always very low compared to other sectors. It is from this allocation that the ministry of agriculture carries out its activities, of which credit disbursement is included. An increase in the allocation, will increase credit availability and access, ceteris paribus. Therefore, the government should increase its allocation to the agricultural sector, with a view to making more funds available to farmers for increased agricultural production.

ii. Financial institutions such as agricultural and community banks, microfinance banks should be established in the zone.

iii. Farmers usually complain of the procedures involved in credit access. The procedures should be reviewed and simpler ones brought forward. Duration for processing loans should also be minimized.

iv. Government agencies and extension service providers, should mobilize farmers to form formidable groups so that they can derive maximum benefit of collective investment, of group savings and access to inputs.

v. Government should help to reduce the interest rate charged on credit so that farmers can apply for credit from formal sources.

vi. The farmers should try to improve on their education, so that they can have knowledge, skills and attitudes to tackle any problem that may arise in accessing credit.

vii. The level of credit needed by farmers should be considered, by ensuring that the amount of credit released by the financial institutions is equivalent to the amount requested by the farmers.

viii. Policy measures for improving access to credit should be developed based on farmers' preferences and needs. Institutional capacity building for both lenders and borrowers should be an integral part of every credit program that will be provided in order to increase agricultural productivity and the income of farmers.

Acknowledgment: We acknowledge the criticisms and contributions of the academia at the Department of Agricultural Economics, University of Nigeria Nsukka, Nigeria, which have helped shape this article into its current form.

\section{REFERENCES}

AJAGBE, F. A. (2012). Application of probit analysis to factors affecting small scale enterprises' decision to take credit: A case study of Oyo State, Nigeria. Asian Economic and Financial Review, 2(8), pp. 1064-1071.

AKINADE, J. O. (2002). Agricultural credit management in Union Bank of Nigeria, Abeokuta Branch. Unpublished M.Sc thesis submitted to the Department of Agricultural Economics, University of Ibadan, Nigeria.

Aku, P. S. (1995). Comparative analysis of NACB and ACGSF loan disbursement to agriculture in Nigeria. Journal of Social and Management Studies, 2, 99-108.

ALI, B. M., AGBO, F. U., UKWUABA, I. C., \& CHIEMELA, C. J. (2017). The effects of interest rates on access to agro credit by farmers in Kaduna State, Nigeria. African Journal of Agricultural Research, 12(43), 3160-8. DOI: $\underline{\text { htps://doi.org/10.5897/AJAR2015.9571 }}$

ANI, D. P. (2015). Market integration and pricing 
efficiency of soyabeans in Benue and Enugu States, Nigeria. Unpublished Ph.D Dissertation presented to the Department of Agricultural Economics, University of Nigeria, Nsukka, Nigeria.

ANYANWU, C. M. (2004). Micro-finance institutions in Nigeria: Policy, practice and potentials. Paper presented at the G24 workshop on "Constraints to Growth in SubSaharan Africa". Pretoria, South Africa. November 29-30. ASOGWA, B. C., ABU, O., \& OCHOCHE, G. E. (2014). Analysis of peasant farmers' access to agricultural credit in Benue State, Nigeria. British Journal of Economics, Management and Trade, 4(10), 1525-43. ISSN: 00161125. Retrieved January 5, 2020, from http://www.sciencedomain.org/reviewhistory.php?iid $=535 \& \mathrm{id}=20 \&$ aid $=4790$

ASSOGBA, P. N., KOKOYE, S. E., YEGBEMEY, R. N., DJENONTIN, J. A., TASSOU, Z., PARDOE, J., \& YABI, J. A. (2017). Determinants of credit access by smallholder farmers in North-East Benin. Journal of Development and Agricultural Economics, 9(8), 210-216. DOI: https://doi.org/10.5897/JDAE2017.0814

AWOTIDE, B. A., ABDOUlAYE, T., ALENE, A. \& MANYONG, V. M. (2015). Impact of access to credit on agricultural productivity: Evidence from smallholder cassava farmers in Nigeria. Milan, Italy, International Conference of Agricultural Economists (ICAE).

BADIRU, I. O. (2010). Review of small farmer access to agricultural credit in Nigeria. Nigeria Strategy Support Program of the International Food Policy Research Institute, Policy Note No. 25.

BASHIR, M. K., MEHMOOD, Y., \& HASSAN, S. (2010). Impact of agricultural credit on productivity of wheat crop: Evidence from Lahore, Punjab, Pakistan. Pakistan Journal of Agricultural Science, 47(4), 405-409. CARTER, M. R. (1989). The impact of credit on peasant productivity and differentiation in Nicaragua. Journal of Development Economics, 31(1), 13-36. DOI: https://doi.org/10.1016/0304-3878(89)90029-1

CARTER, M. R., \& OLINTO, P. (2003). Getting institutions "Right" for whom? Credit constraints and the impact of property rights on the quantity and composition of investment. American Journal of Agricultural Economics, $\quad 85(1), \quad 173-186$. DOI: https://doi.org/10.1111/1467-8276.00111

CBN. CENTRAL BANK OF NIGERIA. (2004). CBN Annual Report. Abuja: CBN.

DBSA. DEVELOPMENT BANK OF SOUTH AFRICA. (2005). Development Report 2005, Agriculture in South African's second Economy (chapter 7)

DIAGNE, A., \& ZELLER, M. (2001). Access to credit and its impact on welfare in Malawi. Research Report 116. Washington DC: International Food Policy Research Institute (IFPRI).

DIXON, J., GULLIVER, A. GIBBON, D., \& HALL, M. (2001). Farming systems and poverty: Improving farmer's livelihood in a changing world. Rome and Washington DC: World Bank. Retrieved March 21, 2019, from http://documents.worldbank.org/curated/en/12625146833 $\underline{1211716 / \text { Farming-systems-and-poverty-improving- }}$ farmers-livelihoods-in-a-changing-world

ESG. ENUGU STATE GOVERNMENT. (2018). About Enugu State. Enugu: Ministry of Information, Enugu
State, Nigeria. Retrieved February 18, 2019, from https://www.enugustate.gov.ng/index.php/elementsdevices/

FEDER, G., LAU, L. J., LIN, J. Y., \& LUO, X. (1990). The Relationship between credit and productivity in Chinese agriculture: A microeconomic model of disequilibrium. American Journal of Agricultural Economics, 72(5), 1151-1157. DOI : 10.2307/1242524

FLETSCHNER, D., GUIRKINGER, C., \& BOUCHER, S. (2010). Risk, credit constraints and financial efficiency in Peruvian agriculture. Journal of Development Studies, 46(6), 981-1002. DOI: https://doi.org/10.1080/00220380903104974

FOLTZ, J. D. (2004). Credit market access and profitability in Tunisian agriculture. Agricultural Economics, 30(3), 229-240. DOI: https://doi.org/10.1111/j.1574-0862.2004.tb00191.x

GHATAK, M., \& GUINNANE, T. W. (1999). The Economics of lending with joint liability: Theory and practice. Journal of Development Economics, 60(1999), 195-228.

GUIRKINGER, C. (2008). Understanding the coexistence of formal and informal credit markets in Piura, Peru. World Development, 36(8), 1436-1452. DOI: https://doi.org/10.1016/j.worlddev.2007.07.002

GUIRKINGER, C., \& BOUCHER, S. R. (2008). Credit constraints and productivity in Peruvian agriculture. Agricultural Economics, 39(3), 295-308. DOI: 10.1111/j.1574-0862.2008.00334

HAZARIKA, G., \& GUHA-KHASNOBIS, B. (2008). Household access to microcredit and children's food security in Rural Malawi: A gender perspective. IZA Discussion Papers, No. 3793. Bonn, Germany: Institute for the Study of Labor. Retrieved February 18, 2019, from http://nbn-resolving.de/urn:nbn:de:101:1-20081126670

IJIOMA, C. J. \& OSONDU, C. K. (2015). Agricultural credit sources and determinants of credit acquisition by farmers in Idemili Local Government Area of Anambra State. Journal of Agricultural Science and Technology, B5(2015), 34-43. DOI: 10.17265/2161-6264/2015.01.004 KOCHAR, A. (1997). An empirical investigation of rationing constraints in rural credit markets in India. Journal of Development Economics, 53(2), 339-371. DOI: https://doi.org/10.1016/S0304-3878(97)00020-5

LAWAL, W. A. (2011). An analysis of government spending on agricultural sector and its contribution to GDP in Nigeria. International Journal of Business and Social Science, 2(20), 244-250.

LINH, T. N., LONG, H. T., CHI, L. V., TAM, L. T., \& LEBAILLY, P. (2019). Access to rural credit markets in developing countries, the case of Vietnam: A literature review. Sustainability, 11(1468), pp. 1-18. DOI: https://doi.org/10.3390/su11051468

MAGAJA, D. \& AGAI, O. G. (N.D.). Access to finance for inclusive agri-business development, Accra, Ghana: 2scale Consortium.

MAIGIDA, D. N. (2001). Empowering women for sustainable development: A workshop on agricultural production technologies for sustainable development of the rural area, Zaria Zone. June 4-6.

MGBAKOR, M. N., UZENDU, P. O. AND NDUBUISI, D. O. (2014). Sources of agricultural credit to small scale 
farmers in Ezeagu Local Government Area of Enugu State Nigeria. Journal of Agricultural and Veterinary Science, 7(8), 11-8.

MILER, F. (1977). Agricultural credit and finance in Africa. U.S.A: Rockefeller Foundation.

MUHAMMAD, N., MUHAMMAD, F. S., SYED, M. A., \& ZATTID, H. (2013). Impact of socioeconomic characteristics of farmers on access to agricultural credit. Sarhad Journal of Agriculture, 29(3), 143-54.

NATIONAL POPULATION COMMISSION (NPC). (2006). The Nigeria Population Census. Retrieved February 20, 2019

NNB. NEPAL NESTRA BANK. (2014). Banking Development and Research Unit, Ohanagadhi Office.

NWARU J. C. (2004). Rural credit markets and resource use in arable crop production in Imo State, Nigeria. Unpublished Ph.D Dissertation submitted to the Department of Agricultural Economics, Michael Okpara University of Agriculture, Umudike, Nigeria.

NWARU, J. C., ESSIEN, U. A., \& ONUOHA, R. E. (2011). Determinants of rural farm loan repayment: Implications for rural credits development in Imo State Nigeria. Journal of Agricultural and Food Science, 2(1), 57-67.

NWARU, J. C., ONYENWEAKU, C. E., \& NWOSU, A. C. (2006). Relative technical efficiency of credit and noncredit user crop farmers. African Crop Science Journal, 14(3), 241-51.
OBWONA, M. (2006). Determinants of technical efficiency differentials amongst small- and medium-scale farmers in Uganda: A case study of tobacco growers. African Economic Research Consortium (AERC) Research Paper 152. Kenya: AERC. 21pp.

OKORUWA, V. O., ABASS, A. B., AKIN-OLAGUNJU, O. A., \& AKINOLA, N. A. (2020). Does institution type affect access to finance for cassava actors in Nigeria? Journal of Agriculture and Food Research, 2(2020), pp. 1-8. https://doi.org/10.1016/j.jafr.2020.100023

OLAGUNJU, F. I., \& AJIBOYE, A. (2010). Agricultural lending decision: A tobit regression analysis. African Journal of Food Agricultural Nutrition and Development, AFJAND, 10(5), 2515-41.

OLOLADE, R. A., \& OLAGUNJU, F. I. (2013). Determinants of access to credit by small holder farmers in Oyo State, Nigeria. Global Journal of Science Frontier, Research, Agriculture and Veterinary Sciences, 13(2), 1622.

PETRICK, M. (2004). A microeconometric analysis of credit rationing in the Polish farm sector. European Review of Agricultural Economics, 31(1), 77-101. DOI: 10.1093/erae/31.1.77

WILLIAM, L. (2008). Nigeria: The Bradt travel guide. UK: Bradt Travel Guides. 342 pp. 